UNDER THE INFLUENCE 



\title{
Under the Influence
}

\section{Putting Peer}

Pressure to Work

\author{
Robert H. Frank
}

PRINCETON UNIVERSITY PRESS

PRINCETON AND OXFORD 
Copyright (c) 2020 by Robert H. Frank

Preface to the paperback edition, copyright $(\odot 2021$ by Robert H. Frank

Requests for permission to reproduce material from this work

should be sent to permissions@press.princeton.edu

Published by Princeton University Press

41 William Street, Princeton, New Jersey 08540

6 Oxford Street, Woodstock, Oxfordshire OX20 ITR

press.princeton.edu

All Rights Reserved

Library of Congress Control Number: 2021939856

First paperback printing, 2021

Paper ISBN 9780691227108

Cloth ISBN 9780691193083

ISBN (e-book) 9780691198828

British Library Cataloging-in-Publication Data is available

Editorial: Joe Jackson and Jacqueline Delaney

Production Editorial: Lauren Lepow

Cover Design: Matt Avery / Monograph

Production: Erin Suydam

Publicity: James Schneider and Caroline Priday

Cover art: iStock

This book has been composed in Adobe Text and Gotham

Printed in the United States of America 
Example, whether it be good or bad, has a powerful influence. -GEORGE WASHINGTON, MARCH 5, 1780 
